() Entomologica Fennica. 3 July 2002

\title{
Population densities and diversity of Calliphoridae (Diptera) around a nickel-copper smelter at Monchegorsk, Northwestern Russia
}

\author{
Mikhail V. Kozlov \& Terry Whitworth
}

Kozlov, M. V. \& Whitworth, T. 2002: Population densities and diversity of Calliphoridae (Diptera) around a nickel-copper smelter at Monchegorsk, Northwestern Russia. — Entomol. Fennica 13: 98-104.

In the summer of 2000, we collected blowflies (Calliphoridae) in ten sites around the Severonikel smelter on the Kola Peninsula. Meat-baited funnel traps (three per site), operated from June 10 to August 30, yielding 973 specimens of ten blowfly species; eight species are reported from the Kola Peninsula for the first time. The maximum catch (495 individuals), obtained at the site located $1 \mathrm{~km}$ from the smelter, was due to the synanthropic preferences of the two most common species, Protophormia terraenovae and Cynomya mortuorum. Neither total abundance nor diversity of blowflies attracted by meat baits changed along the pollution gradient.

Mikhail V. Kozlov, Section of Ecology, University of Turku, FIN-20014 Turku,Finland;E-mail:mikoz@utu.fi

Terry Whitworth, Whitworth Pest Control Inc., 3707 - 96th St. E, Tacoma, Washington 98446, U.S.A.

Received 15 October 2001, accepted 21 January 2002

\section{Introduction}

Decomposition of organic matter and subsequent mineralization are vital to ecosystem functioning and productivity (Seastedt 1984). Pollutants, such as heavy metals, may slow down decomposition processes, mainly due to adverse effects on microorganisms and soil inhabiting fauna (Bååth 1989, Bengtsson \& Tranvik 1989, Heliövaara \& Väisänen 1993). However, studies of decomposition processes near the polluters have so far been limited to plant litter (Freedman \& Hutchinson 1980, Neuvonen \& Suomela 1990, Berg et al. 1991), and the effects of pollution on necrophagous insects remain completely unknown. In particular, no data on blowflies (Calliphoridae) were included in the review by Kozlov (1990), while
Heliövaara \& Väisänen (1993) mentioned only an increase in blowfly density in connection with urbanization.

The purpose of the present study was to document species richness and abundance of blowflies, attracted to meat baits, along a strong pollution gradient in the northern boreal forest zone.

\section{Material and methods}

\subsection{Study area and study sites}

The study was conducted in the lowland forest zone of the Kola Peninsula, northwestern Russia, north of the Polar Circle. The study sites were located within $65 \mathrm{~km}$ of the Severonikel nickel-copper smelter at Monchegorsk 
$\left(67^{\circ} 55^{\prime} \mathrm{N}, 32^{\circ} 48^{\prime} \mathrm{E}\right)$. This smelter was officially opened in 1937 , but regular work began only in 1946-1947. In the late 1980s and early 1990s, it was one of the largest European sources of aerial pollution, predominantly of sulphur dioxide and heavy metals (Anonymous 1994). In 1990, it emitted $2.32 \times 10^{8} \mathrm{~kg} \mathrm{SO}_{2}, 2.7 \times 10^{6} \mathrm{~kg} \mathrm{Ni}$ and $1.8 \times 10^{6} \mathrm{~kg}$ $\mathrm{Cu}$; since that time, emissions have steadily declined, reaching $0.46 \times 10^{8} \mathrm{~kg} \mathrm{SO}_{2}, 1.1 \times 10^{6} \mathrm{~kg} \mathrm{Ni}$ and $0.9 \times 10^{6} \mathrm{~kg} \mathrm{Cu}$ in 1999 (Dubrovskij 2000).

Before the smelter started to operate, the dominant type of lowland vegetation in the areas south of Monchegorsk was spruce forest (Bobrova \& Kashurin 1936). Vast quantities of sulphur and heavy metals emitted during the last 60 years have caused widespread destruction of soils and vegetation around the smelter (Kozlov \& Haukioja 1995, Rigina $\&$ Kozlov 1999). The total area influenced by aerial pollution recently exceeded $10000 \mathrm{~km}^{2}$, with industrial barrens covering tens of square kilometres (Kryuchkov 1993, Tikkanen \& Niemelä 1995). For vegetation characteristics, concentrations of pollutants, and levels of environmental disturbances in the study area, see Barkan (1993), Koroleva (1993), Kryuchkov (1993), Kozlov \& Haukioja (1995), Kozlov et al. (1995), Rigina \& Kozlov (1999) and Zvereva \& Kozlov (2000)

The sites were coded with the distance $(\mathrm{km})$ and direction from the smelter, e.g. $14 \mathrm{~S}$ for the site at $14-\mathrm{km}$ distance South of Monchegorsk. The sampled habitats were classified as follows: industrial barrens $(1 \mathrm{~N}, 7 \mathrm{~S})$, birch transitional community $(5 \mathrm{~N}, 14 \mathrm{~S})$, severely damaged forest $(11 \mathrm{~N}, 20 \mathrm{~S})$, slightly damaged forest (15N, 29S) and nearly undamaged forest (41S, 65SE).

\subsection{Pollution loads at the study sites}

The emissions of any smelter consist of dozens of substances, many of which may cause toxic effects. The main pollutants (in terms of total weight) in the study area are sulphur dioxide and heavy metals, predominantly nickel and copper. Concentrations of all pollutants in all media (ambient air, soils, plants, animals) decrease proportionally with increase of distance from the smelter (Barcan 1993, Barcan et al. 1993, Kozlov et al. 1995, Ruohomäki et al. 1996, Valkama \& Kozlov 2001). Since it is impossible to attribute the effects observed in the course of field studies to any of the individual pollutants, we have chosen, like in some earlier papers (Ruohomäki et al. 1996, Valkama \& Kozlov 2001), to use distance from the smelter as a rough measure of pollution load in our study sites.

\subsection{Trapping and processing of samples}

Funnel bait traps were made from 2-1 plastic bottles. The bottom of the bottle was removed and replaced by a screen cone made from a plastic net (cell size $1.5 \times 1 \mathrm{~mm}$ ). The traps were established on 10 June 2000, which corresponds to the late spring in the study region: in the site most distant from the smelter the ground was still covered by snow. Traps (three per site) were hung on tree branches, some 1-1.5 m above the ground, $15-20 \mathrm{~m}$ apart. The small (5-10 g) piece of beef (placed in a plastic vial, which hangs inside the bottle) was used as bait. New baits were added on July 5 and 30 , i.e. with 25-day intervals; the old one remained in the trap until the nearest sampling date. Flies were killed by insecticide (a piece of DDVP strip attached to the inner surface of the bottle). Traps were emptied in 10-day intervals until 30 August 2000; the individual catches were stored dry in boxes between layers of tissue. Most specimens were identified to species except for a few that were damaged or discolored.

\subsection{Data analysis}

Among-site variation in the numbers of individuals in catches was analysed by General Linear Model, type III sum of squares (SAS Institute 1990); traps were nested within sampling sites; means were compared by Duncan Multiple Range test. The Bonferroni correction was applied to avoid inflation of the probability levels. Rarefaction-corrected, site-specific species richness (expected number of species in the random subsample of 25 individuals) was estimated according to Krebs (1989), except for site 7S. The value for that site was obtained by graphical approximation (algorithm by Krebs does not allow to estimate the number of species in a sample which is larger than the original one). Shannon diversity index was calculated by using natural logarithms. Distance to the smelter was log-transformed prior the correlation analysis. Power of the correlation analysis was calculated according to Zar (1984).

\section{Results}

\subsection{Species composition}

We collected 973 specimens of blowflies, among which 963 specimens were determined to the species level (Table 1). Additionally, several specimens were occasionally collected by colour traps; they are not included in the further analysis. Seven of ten species collected by meat-baited traps ( $\mathrm{Cal}$ liphora vicina R.-D., C. loewi End., C. uralensis Vill., C. subalpina Ringd., C. vomitoria L., $C$. grahami and Lucilla silvarum Meig.), and Protocalliphora chrysorrhoea Meig. captured by colour trap in Apatity, are reported from the Kola Peninsula for the first time. 


\subsection{Total abundance and species richness}

The number of collected specimens (all species pooled) depended on study site and collecting date, as well as on interaction between these two factors; catches varied among traps nested within study site (Table 2). However, Duncan Multiple Range test showed that all among-site variation is associated with the deviating catches in site $1 \mathrm{~N}$ $\left(2.06 \pm 0.67\right.$ exx trap $^{-1}$ day $\left.^{-1}\right)$, whereas catches in the remaining nine sites ranged from 0.03 to 0.41 exx trap ${ }^{-1}$ day $^{-1}$ and did not differ from each other at the probability level $P=0.05$. If the deviating site is excluded, the site-specific catches did not correlate with the distance to the smelter (Fig. 1a).

Direct analysis of the species number in the catches would be inappropriate because of the pronounced variation in the number of collected individuals. Therefore we calculated rarefactioncorrected site-specific species richness, which showed no correlation with the distance to the smelter (Fig. 1b). Shannon diversity index was also independent of the distance from the smelter (Fig. 1c).

In spite of the relatively low number of study sites, the power of the correlation analysis (total abundance $-94 \%$, rarefaction-corrected species richness - 91\%, Shannon diversity index $79 \%$ ) was high enough to reject the hypothesis that severe environmental pollution influences the abundance and diversity of Calliphoridae $(\alpha=0.05)$.

Table 1. Total site-specific catches of Calliphoridae.

\begin{tabular}{lrrrrrrrrrr}
\hline Species & \multicolumn{10}{c}{ Study sites $^{1}$} \\
\cline { 2 - 11 } & $15 \mathrm{~N}$ & $11 \mathrm{~N}$ & $5 \mathrm{~N}$ & $1 \mathrm{~N}$ & $7 \mathrm{~S}$ & $14 \mathrm{~S}$ & $20 \mathrm{~S}$ & $29 S$ & $41 S$ & $65 S$ \\
\hline Calliphora vicina & 0 & 0 & 2 & 4 & 0 & 0 & 0 & 0 & 0 & 0 \\
C. loewi & 8 & 1 & 0 & 6 & 0 & 5 & 51 & 8 & 13 & 14 \\
C. uralensis & 0 & 2 & 0 & 4 & 0 & 5 & 3 & 4 & 0 & 1 \\
C. subalpina & 0 & 0 & 1 & 0 & 0 & 0 & 1 & 0 & 0 & 0 \\
C. vomitoria & 0 & 0 & 0 & 0 & 0 & 0 & 1 & 5 & 0 & 1 \\
Cynomia mortuorum & 12 & 20 & 10 & 43 & 6 & 6 & 8 & 18 & 7 & 14 \\
Protophormia terraenovae & 66 & 75 & 22 & 433 & 1 & 5 & 17 & 11 & 4 & 35 \\
Lucilia illustris & 0 & 0 & 0 & 0 & 0 & 6 & 4 & 0 & 0 & 1 \\
Other species & 2 & 0 & 0 & 5 & 0 & 1 & 2 & 0 & 0 & 0 \\
Total catch & 88 & 98 & 35 & 495 & 7 & 28 & 87 & 46 & 24 & 65 \\
\hline
\end{tabular}

${ }^{1}$ Study sites labelled by distance $(\mathrm{km})$ and direction from the smelter at Monchegorsk

Table 2. Sources of variation in catches of blowfly species ( $F$-values and experimentwise probability levels estimated by Bonferroni method: ${ }^{*} p<0.05,{ }^{* *} p<0.01$; Error: $\mathrm{df}=140$ ).

\begin{tabular}{lcccc}
\hline Species & \multicolumn{4}{c}{ Source of variation } \\
\cline { 2 - 5 } & $\begin{array}{c}\text { Site } \\
(\mathrm{df}=9)\end{array}$ & $\begin{array}{c}\text { Trap }(\text { Site }) \\
(\mathrm{df}=20)\end{array}$ & $\begin{array}{c}\text { Date } \\
(\mathrm{df}=7)\end{array}$ & $\begin{array}{c}\text { Site } \times \text { Date } \\
\text { (df }=63)\end{array}$ \\
\hline Calliphora vicina & 1.45 & 0.64 & 0.68 & 0.88 \\
C. loewi & $10.00^{\star *}$ & 2.03 & $5.48^{* *}$ & 1.42 \\
C. uralensis & 1.16 & 0.69 & $4.80^{* *}$ & 0.92 \\
C. subalpina & 0.89 & 1.00 & 0.86 & 1.02 \\
C. vomitoria & 1.64 & 1.00 & 1.59 & $1.82^{*}$ \\
Cynomia mortuorum & 2.13 & 2.20 & $4.38^{\star *}$ & 1.11 \\
Protophormia terraenovae & $14.33^{* *}$ & $2.49^{*}$ & $7.11^{* *}$ & $3.10^{* *}$ \\
Lucilia illustris & 1.67 & 1.00 & 1.61 & $1.88^{*}$ \\
Total catch & $11.86^{\star *}$ & $2.74^{* *}$ & $7.83^{* *}$ & $2.50^{* *}$ \\
\hline
\end{tabular}




\subsection{Abundances of individual species}

Catches of the three most abundant species (Protophormia terraenovae R.-D., Cynomya mortuorum L., C. lowei) demonstrated significant among-site variation, whereas catches of the five less abundant species did not depend on study site (Table 2). The highest catches of $P$. terraenovae and $C$. mortuorum were obtained at site $1 \mathrm{~N}$ (Table 1); catches in the remaining sites were not statistically different (Duncan's Multiple Range test, $P=0.05)$ and did not correlate with the distance to the smelter $(r=-0.07, n=9$ sites, $P=0.86$ and $r=0.19, n=9, P=0.63)$ The peak catch of $C$. lowe $i$ was obtained at site 20S (Table 1); catches in the remaining sites were not statistically different (Duncan's Multiple Range test, $P=0.05$ ) and correlation with the distance from the smelter was not significant $(r=0.38, n=9, P=0.31)$.

\section{Discussion}

\subsection{Faunistics of blowflies}

$P$. terranovae and $C$. mortuorum were found in Khibiny Mts by Fridolin (1936). Grunin (1970) reported two further species, Bellardia stricta (Vill.) and Lucilia magnicornis (Siebke). Rognes (1991) apparently overlooked the mentioned publications by Russian authors; for the Kola Peninsula (provence $\mathrm{Lr}$ in his book) he listed only four species: Bellardia pubicornis Zett., Trypocalliphora braueri Hend., L. magnicornis and L. illustris. With the addition of our data, blowfly fauna of the Kola Peninsula now totals 15 species, the same number that is found in the much better investigated Finnish Lapland: 15 species of Calliphoridae are known from the provinces $L i$ and Lke (Rognes 1991). All four species reported from Finnish Lapland but not yet recorded from the Kola Peninsula (Calliphora genarum Zett., C. stelviana B. \& B., P. nuortevai Grun. and Protophormia atriceps Zett.) are almost certainly to be found there; though of them, only C. genarum was bait-trapped in Northern Finland (Nuorteva 1963). Since all these species (except for C. stelviana) are rare (Rognes 1991), and Protocalliphora species are parasitic and thus not attracted by meat-baits, we conclude that our sample was sufficiently representative of the study re-
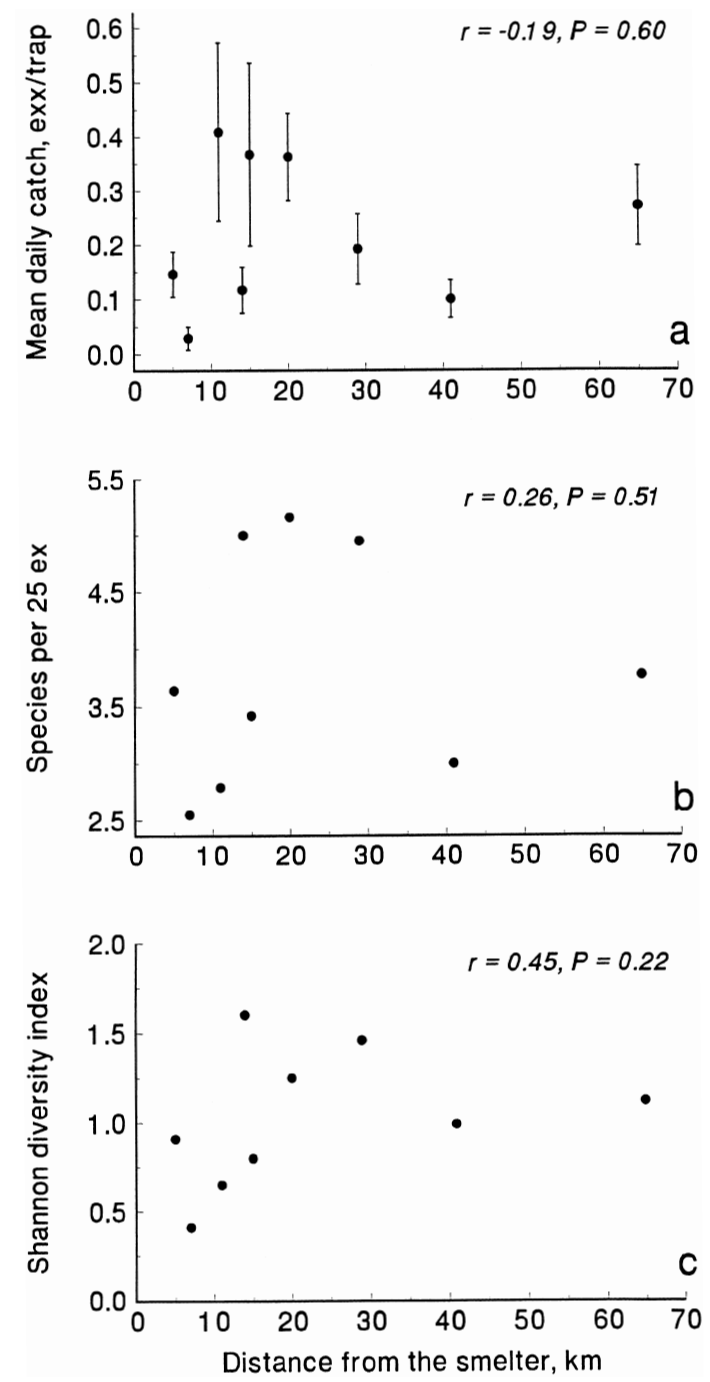

Fig. 1. Characteristics of blowfly assemblages in relation to the distance from the smelter (site $1 \mathrm{~N}$ excluded). - a. Mean catches. - b. Rarefactioncorrected species richness (expected number of species in a random subsample of 25 individuals). c. Shannon diversity index, calculated on the basis of natural logarithms.

gion in terms of the composition of blowfly species which can utilize carrion resources.

\subsection{Effects of synanthropy}

One of our sampling sites $(1 \mathrm{~N})$ was located at $1-\mathrm{km}$ distance from the smelter, and at $2 \mathrm{~km}$ 
distance from the nearest living blocks of the city of Monchegorsk. However, two gasoline stations were located at the distances 500 and $700 \mathrm{~m}$ on both sides of this trapping site. When designing the study, we expected that these distances would be sufficient to prevent migration of the synantropic species. However, our results demonstrated that $P$. terraenovae successfully covers this distance (or there were some other suitable habitats overlooked in the course of fieldwork), but was most likely not able to reach the next sites, located 3 to $5 \mathrm{~km}$ from the living blocks (sites $5 \mathrm{~N}$ and $7 \mathrm{~S}$, respectively). Since concentrations of pollutants and habitat deterioration at these three sites $(5 \mathrm{~N}, 1 \mathrm{~N}, 7 \mathrm{~S})$ are at about the same level (Kozlov et al. 1995, Valkama \& Kozlov 2001), we conclude that the peak density at site $1 \mathrm{~N}$ is associated with the proximity to human settlement, not with extreme pollution load, and exclude this site from the analysis aimed at detecting effects of pollution. All other trapping sites were far away from any settlement.

Although our sampling design does not allow calculation of the synanthropic index developed by Nuorteva (1963), some comparisons with the earlier studies on blowfly association with human settlements are still possible. Our results are in good agreement with data from Northern Finland (Nuorteva 1963); in particular, we detected strong synanthropy of $P$. terraenovae (the catch in site $1 \mathrm{~N}$ was 18 times as high as the mean catch in any other site) and moderate synanthropy of $C$. mortuorum (the catch in site $1 \mathrm{~N}$ was 5 times as high as the mean catch in any other site). Interestingly, Nuorteva (1963) classified C. mortuorum as a more or less 'neutral' species, although his data from subarctic Finland (like our data from Kola Peninsula) demonstrate a moderate synanthropy. In contrast, C. loewi demonstrated moderate avoidance of human settlements (the catch in site $1 \mathrm{~N}$ is only half of the mean catch in any other site), the same pattern as reported by Nuorteva (1963). Neither C. voimitoria nor $L$. illustris were trapped at site $1 \mathrm{~N}$, although in subarctic Finland they exhibited moderate to high synanthropy (Nuorteva 1963). However, our sample sizes are too small to invoke a difference in biology of these blowfly species in the two adjacent areas.

\subsection{Does pollution matter?}

Both environmental contamination (in terms of toxicity of pollutants) and pollution-induced habitat deterioration were expected to affect communities of carrion-feeding blowflies via changes in resource availability (density/biomass of vertebrates declines and mortality increases with proximity to the smelter; Gilyazov 1993a, Kataev et al. 1994, Kataev 1995), habitat characteristics (air in industrial barrens in spring and summer is $1-3{ }^{\circ} \mathrm{C}$ warmer than in unpolluted forests, mainly because forest decline allows direct sunlight to reach the ground; Kozlov \& Haukioja 1998), or toxicity of larval food (metal concentrations in tissues of local birds and mammals exceed the background levels by a factor of 2-4; Gilyazov 1993b, Kataev 1995). However, when site $1 \mathrm{~N}$ was excluded from the analysis, both total catches and diversity of blowflies appeared independent of pollution load (as approximated by the distance to the smelter). Similarly, the catches of individual species, including $C$. mortuorum, which is known to be associated with burrows of small mammals (Nuorteva \& Vesikari 1966), did not change with increase in pollution; only phenology of some species may have been shifted by these pollution-induced environmental changes, as indicated by significant site $\times$ date interactions in the GLM analysis (Table 2). This result clearly contradicts our expectations; however, shortage of data on the use of food resources by the involved blowfly species makes any speculations on the underlying mechanisms premature. Furthermore, relatively high variation in catches among individual traps (Table 2) suggests that we may have failed to detect possible minor effects of pollution on the abundance of blowflies due to low number of replicates (three traps at each study site).

Interestingly, density of burying beetle Nicrophorus vespilloides Hbst., collected by the same set of traps, peaked at the intermediate levels of pollution (sites 20S and 29S), being there 2-4 times as high as in the most distant (control) sites. This density pattern fits well the distribution of carrion resources expected from the data on density and mortality of birds and small mammals (Kozlov \& Zvereva unpubl.). The differences in distribution of burying beetles and blowflies may indicate that Calliphoridae can use a larger variety of resources than the burying beetle. 
Acknowledgements. We thank A. Vassiliev and V. Zverev for their assistance in fieldwork and sorting the catches. E. Zvereva and two anonymous referees provided valuable comments on an earlier draft of the paper.

\section{References}

Bååth, E. 1989: Effects of heavy metals on soil microbial processes and populations (a review). — Water, Air, and Soil Pollution 47: 335-379.

Barkan, V. S., Pankratova, R. P. \& Silina, A. V. 1993: Soil contamination by nickel and copper in area polluted by "Severonikel" smelter complex. — In: Kozlov, M. V., Haukioja, E. \& Yarmishko, V. T. (eds.), Aerial Pollution in Kola Peninsula: Proceedings of the International Workshop, 14-16 April 1992, St. Petersburg. Kola Science Centre, Apatity, Russia, pp. 119-147.

Barkan, V. S. 1993: Measurement of atmospheric concentrations of sulphur dioxide by passive lead dioxide absorbers. - In: Kozlov, M. V., Haukioja, E. \& Yarmishko, V. T. (eds.), Aerial Pollution in Kola Peninsula: Proceedings of the International Workshop, 14 16 April 1992, St. Petersburg. Kola Science Centre, Apatity, Russia, pp. 90-98.

Bengtsson, G. \& Tranvik, L. 1989: Critical metal concentrations for forest soil invertebrates. - Water, Air, and Soil Pollution 47: 381-417.

Berg, B., Ekbohm, G., Söderström, B. \& Staaf, H. 1991: Reduction of decomposition rates of Scots pine needle litter due to heavy metal pollution. - Water, Air, and Soil Pollution 59: 165-177.

Freedman, B. \& Hutchinson, T. C. 1980: Effects of smelter pollutants on forest litter decomposition near a nickelcopper smelter at Sudbury, Ontario. - Can. J. Bot. 58: 1722-1736.

Fridolin, V. J. 1936: [Community of animals and plants of Chibiny mountain area: Biocenothical investigations in 1930-1935.] — Acad. of Sci., Moscow \& Leningrad. [In Russian].

Gilyazov, A. S. 1993a: Contents of metals in some birds of the Lapland reserve. - In: Kozlov, M. V., Haukioja, E. \& Yarmishko, V. T. (eds.), Aerial Pollution in Kola Peninsula: Proceedings of the International Workshop, 14-16 April 1992, St. Petersburg. Kola Science Centre, Apatity, Russia, pp. 206-209.

Gilyazov, A. S. 1993b. Air pollution impact on the bird communities of the Lapland biosphere reserve. - In: Kozlov, M. V., Haukioja, E. \& Yarmishko, V. T. (eds.), Aerial Pollution in Kola Peninsula: Proceedings of the International Workshop, 14-16 April 1992, St. Petersburg. Kola Science Centre, Apatity, Russia, pp. 383-390.

Gilyazov, A. S. \& Panichev, N. A. 1994: [Metal concentrations in tissues of willow ptarmigan (Lagopus lagopus L.) from industrially contaminated areas of the Kola Peninsula.] — In: Degteva, S. V. (ed.), [Development of the North and Recultivation Problems: Reports on 2nd International Conference, Syktyvkar, April 25-28 1994.] Institute of Biology, Syktyvkar, pp. 254-260. [In Russian].

Grunin, K. J. 1970: [Fam. Calliphoridae]. — In: Bei-Bienko, G. J. (ed.): [Key to the insects of the European Part of the U.S.S.R. Vol. 5: Flies, fleas, pt. 2.] — Nauka, Leningrad, pp. 607-624. [In Russian].

Heliövaara, K. \& Väisänen, R. 1993: Insects and pollution. - CRC-Press, Florida, 393 pp.

Kataev, G. D. 1995. Small mammals. - In: Sytchev, V. V. (ed.), Forest Ecosystems of Kola Peninsula under Atmospheric Pollution Influence of Smelters. Russian Academy of Sciences, St. Petersburg, Russia, pp. 102110. [In Russian].

Kataev, G. D., Suomela, J. \& Palokangas, P. 1994. Densities of microtine rodents along a pollution gradient from a copper-nickel smelter. - Oecologia 97: 491-498.

Kozlov, M. V. 1990: [Impact of anthropogene factors on the populations of terrestrial insects] — VINITI, Moscow. 192 pp. [In Russian].

Kozlov, M. V. \& Haukioja, E. 1995: Pollution-related environmental gradients around the "Severonikel" smelter complex on Kola Peninsula, Northwestern Russia. In: Munawar, M. \& Luotola, M. (eds.), The contaminants in the nordic ecosystem: the dynamics, processes and fate. Ecovision World Monograph Series, S. P. B. Academic Publishing, The Netherlands, pp. 59-69.

Kozlov, M. V. \& Haukioja, E. 1998: Microclimate changes along a strong pollution gradient in northern boreal forest zone. - In: Uso, J. L., Brebbia, C. A. \& Power, H. (eds.), Ecosystems and sustainable development (Advances in Ecological Sciences, vol. 1). Computation Mechanics Publ., Southampton. pp. 603-614.

Kozlov, M. V., Haukioja, E., Bakhtiarov, A. V. \& Stroganov, D. N. 1995: Heavy metals in birch leaves around a nickel-copper smelter at Monchegorsk, Northwestern Russia. — Environ. Pollut. 90: 291-299.

Krebs, C. J. 1989: Ecological methodology. - Harper \& Row, NY, 654 p.

Neuvonen, S. \& Suomela, J. 1990: The effects of simulated acid rain on pine needle and birch leaf litter decomposition. - J. Appl. Ecol. 27: 857-872.

Nuorteva, P. 1963: Synanthropy of blowflies (Dipt., Calliphoridae) in Finland. - Suomen Hyönt. Aikak. 29: 1-49.

Nuorteva, P. \& Vesikari, T. 1966: The synanthropy of blowflies (Diptera, Calliphoridae) on the coast of the Arctic Ocean. - Ann. Med. Exp. Fenn. 44: 544-548.

Rognes, K. 1991: Blowflies (Diptera, Calliphoridae) of Fennoscandia and Denmark. (Fauna Entomologica Scandinavica 24). - E. J. Brill \& Scandinavian Science Press Ltd., Leiden. 272 pp.

Ruohomäki, K., Kaitaniemi, P., Kozlov, M. V., Tammaru, T. \& Haukioja, E. 1996: Density and performance of Epirrita autumnata (Lep., Geometridae) along three air pollution gradients in northern Europe. - J. Appl. Ecol. 33: 773-785.

SAS Institute 1990: SAS/Stat. User's guide, version 6.0. - 
SAS Institute, Cary, N.C. 1686 pp.

Seastedt, T. R. 1984: The role of microarthropods in decomposition and mineralization processes. - Annu. Rev. Entomol. 29: 25-46.

Valkama, J. \& Kozlov, M. V. 2001: Impact of climatic fac- tors on developmental stability of mountain birches growing in a contaminated area. - J. Appl. Ecol. 38: 665-673.

Zar, J. H. 1984: Biostatistical Analysis, 2nd edn. —PrenticeHall International, London. 718 pp. 